\author{
Dobrosława Wężowicz-Ziółkowska (iD) https://orcid.org/0000-0001-8423-9198 \\ Uniwersytet Śląski \\ dobroslawa.wezowicz-ziolkowska@us.edu.pl
}

\title{
Kultura ludowa - restytucja czy zawłaszczenie?
}

\section{Folk Culture - Restitution or Appropriation?}

Abstract: The objective of the article is reflection on folk culture in the context of knowledge about the memory and knowledge about the past, deepened by the contemplation of mechanisms that appropriate the secondary pasts through the discourses of the dominating groups. The author argues that the traditional folk (or so-called peasant) culture is nowadays a culture without a subject and the ideological selection sieve and processes of globalisation only contributed to its whole areas falling into oblivion or being denied, while selectively keeping only those aspects which can easily undergo its institutionalised restitution. Pointing to the process of restitution being embroiled in the appropriating politics of memory, the author argues with the opinion of Barbara Fatyga who views folk culture as the modern popular culture.

Keywords: folk culture, secondary pasts, restitution, appropriation, memory/oblivion

Streszczenie: Celem artykułu jest namysł nad kulturą ludową w kontekście wiedzy o pamięci i wiedzy o przeszłości, pogłębiony o refleksję nad mechanizmami zawłaszczania przeszłości podrzędnych przez dyskursy grup dominujących. Autorka stawia tezę, że tradycyjna kultura ludowa (zwana też chłopska) jest obecnie kulturą bez podmiotu, a ideologiczne sito selekcji i procesy globalizacyjne przyczyniły się do zapomnienia/wyparcia całych jej obszarów, zachowując wybiórczo jedynie to, co łatwo może podlegać jej instytucjonalnej restytucji. Wskazując na uwikłania procesu restytuowania w polityki pamięci zawłaszczającej, podejmuje też polemikę ze stanowiskiem Barbary Fatygi, której zdaniem kultura ludowa jest współczesną kulturą popularną.

Słowa kluczowe: kultura ludowa, przeszłości podrzędne, restytucja, zawłaszczenie, pamięćl zapominanie 
Podrzędne przeszłości są jak twarde supły, które wystają i zniekształcają gładko utkaną powierzchnię materiału.

\section{Dipesh Chakrabarty, Historie mniejszości, przesztości podrzędne}

Celem tego artykułu jest namysł nad kulturą ludową w kontekście wiedzy o pamięci i wiedzy o przeszłości - dwóch obszarów nowej humanistyki, których potencjał metodologiczny i dokonania wydają się dzisiaj (oprócz ekohumanistyki) najlepiej odpowiadać poznawczym wyzwaniom współczesności, wydatnie przy tym zmieniając jej obraz. Do jego przekształcenia znacznie też przyczyniła się perspektywa postkolonialna ze znamienną rekonfiguracją tematyki badawczej, zasadniczo przebudowująca pole programów badawczych minionego półwiecza, w tym i pole produkcji kulturowej. Coraz wyraźniej własnym głosem mówią w nim ci, o których upominała się Gayatri Chakravorty Spivak, pytając, „czy mogą przemówić?”. Sytuowanie rozważań nad kulturą ludową w Polsce (z niepokojącą poznawczo, bo unifikującą możliwością sformułowania „polską kulturą ludową ${ }^{2}$ ) w wyżej zakreślonym kontekście nie powinno tu dziwić, ponieważ dyskusja na temat jej uwikłań w polityki pamięci i władzy trwa u nas przynajmniej od czasów Stanisława Staszica ${ }^{3}$, choć, oczywiście, bez przywoływania instrumentarium wypracowanego przez memory studies, subaltern studies czy teorię Pierre'a Bourdieu ${ }^{4}$. To nowe instrumentarium, w moim odczuciu, pozwala jednak dziś na precyzyjniejsze dookreślenie wspomnianych wyżej relacji, ujmowanych przez Rocha Sulimę jako „przeklęty problem” drugiej kultury polskiej, „czyli kultury ludowej jako własnej kultury "obcej «" 5 . Czy ów przeklęty problem istnieje w dalszym ciągu? Czy w ogóle jest jeszcze ta kultura z przymiotnikiem wskazującym, do kogo „należy”?

${ }^{1}$ G.Ch. Spivak, Czy podporzadkowani inni mogá przemówić?, tłum. E. Majewska, „Krytyka Polityczna" 2010, 24-25, s. 196-239

2 Jak zauważał już bowiem Stefan Czarnowski, rozsądnie akcentujący odrębności lokalne, rejestrowane wśród społeczności chłopskiej, unifikujące spojrzenie na tę kulturę jest nadmiernym uproszczeniem, ponieważ „Poszczególne wsie różnią się strojem, obyczajami, obrzędami, przemysłami domowymi. Są wsie, trudniące się dodatkowo, obok rolnictwa, koszykarstwem, garncarstwem, koronkarstwem itd. Są wsie kamieniarzy. Są wsie, skąd cała młodzież bezrolna udaje się na roboty sezonowe w dalekie okolice, podczas gdy ze wsi sąsiednich nie wychodzi nikt. Są inne, z których nieomal w każdej rodzinie jedno przynajmniej dziecko uczęszcza do szkół średnich, i są inne sąsiednie, gdzie ogół mieszkańców nie życzy sobie nawet szkoły powszechnej (...). Są wsie, prenumerujące i czytające pisma, obok całych wsi, lekceważących czytelnictwo, wsie nabożne, prawowiernie katolickie obok wsi wolnomyślnych, skłaniających się ku tej czy innej schizmie". S. Czarnowski, Podtoże ruchu chtopskiego [w:] tegoż, Dzieta, t. 2, Warszawa 1956, s. 169.

3 S. Staszic, Przestrogi dla Polski, Warszawa 1790.

${ }^{4}$ Teoria ta, według mnie, stanowi istotny „pas heurystyki pozytywnej” (zgodnie z rozpoznaniami Imrego Lakatosa) „twardego rdzenia” studiów postkolonialnych. Zob. I. Lakatos, Pisma z filozofii nauk empirycznych, tłum. W. Sady; przekład przejrzał W. Krajewski, Warszawa 1995.

5 R. Sulima, Mity polskie i mity ludowe [w:] tegoż, Gtosy tradycji, Warszawa 2001, s. 98. 
Przywoływany tu Sulima we wspomnianym szkicu zdecydowanie stwierdza: „kultura ludowa umarła”, choć „pozostaje nadal wyrazista jako kultura symboliczna", choć żyje jej mit. Jestem tego samego zdania. W każdym razie obecnie kultura ta jawi się jako kultura bez podmiotu, którego własność prymarnie miała stanowić, ponieważ tworząca ją formacja (nazywana też warstwą/ klasą włościańską, chłopską, ludową ${ }^{8}$ ) odeszła w niepamięć wraz z przypadającą na wiek XX demokratyzacją społeczeństwa polskiego, uznawanego dziś za bezklasowe. Prowadzące do „wysadzania relacji społecznych z kontekstów lokalnych i ich odtwarzania na niezmierzonych obszarach czasu i przestrzeni" ${ }^{9}$ mechanizmy globalizacyjne zdecydowanie sprawiły, że mówiąc dziś o kulturze ludowej, z pewnością nie możemy odnosić jej do desygnatu, opisywanego jeszcze przez Floriana Znanieckiego, Józefa Chałasińskiego, Józefa Bursztę, Stanisława Dobrowolskiego czy innych. Na swój sposób daje temu również wyraz artykuł Iwony Kabzińskiej przygotowany z okazji jubileuszu 60-lecia czasopisma „Etnografia Polska”. Charakteryzując w nim rozwój tego organu Instytutu Archeologii i Etnologii PAN, ale przy sposobności i przemiany etnografii jako dyscypliny, stwierdza ona: „Od dawna nie piszemy o "kulturze chłopstwa" $\mathrm{i} »$ klasy robotniczej«, ani o problemach etnogenezy czy »reliktach kultury ludowej«. Zmieniają się problemy badawcze, terminologia, teren badań, język opisu" ${ }^{10}$. W istocie ciągłość trwania osadnictwa wiejskiego (zgodnie z danymi GUS na rok 2017 39,9 \% populacji stanowi ludność wiejska) nie zmienia raczej tego, że kultura ludowa z jej, wykazywanymi przez Kazimierza Dobrowolskiego $^{11}$, Józefa Bursztę ${ }^{12}$ czy Ludwika Stommę $e^{13}$, atrybutami (izolacją przestrzenną i świadomościową, rytualizmem, tradycjonalizmem, religijnością, prymatem ustnego przekazu tradycji) nie ma już racji bytu, a ściślej mówiąc

${ }^{6}$ Tamże, s. 102.

7 Tamże.

${ }^{8}$ Co sprawiło, że przyjęło się używanie pojęcia „kultura ludowa” wymiennie z pojęciem „kultura chłopska”, na co wskazuje między innymi Wojciech Burszta, pisząc: „W polskiej etnografii po II wojnie światowej ścierały się dwa nurty widzenia kultury chłopskiej zwanej ludową". W. Burszta, Etnografia ludowości [w:] Kultura ludowa. Teorie - praktyki-polityki, red. B. Fatyga, R. Michalski, Warszawa 2014, s. 107. Jednocześnie zastrzega wszakże, za Józefem Bursztą, iż „chłopskość” i „ludowość”: „Nie są to jednak terminy równoznaczne; drugi obejmuje kilka kategorii warstw społeczeństwa klasowego (ludność wiejską, miejski plebs, rzemieślników i inne grupy zawodowe wytwórców dóbr materialnych), podczas gdy pierwszy termin odnosi się do jednej tylko warstwy (czy klasy) społeczeństwa, tj. chłopów”. Tamże, s. 113.

9 A. Giddens, Nowoczesność i tożsamość. "Ja” i spoteczeństwo w epoce późnej nowoczesności, tłum. A. Szulżycka, Warszawa 2002, s. 26.

${ }^{10}$ I. Kabzińska, Jubileusz sześćdziesięciolecia „Etnografii Polskiej”. Kontynuacja początkowych zatożeń - nowe nurty i tematy - pytania i refleksje, „Etnografia Polska” 2016, t. LX, z. 1-2, s. 10.

${ }^{11}$ K. Dobrowolski, Studia nad teoria kultury ludowej, „Etnografia Polska” 1961, t. 4.

12 J. Burszta, Kultura ludowa [w:] Stownik etnologiczny: terminy ogólne, red. Z. Staszczak, Warszawa-Poznań 1987, s. 195-198.

${ }^{13}$ L. Stomma, Determinanty polskiej kultury ludowej XIX wieku, „Konteksty. Polska Sztuka Ludowa” 1978, nr 3; tenże, Antropologia kultury wsi polskiej XIX wieku, Warszawa 1986. 
racji praxis. Jawi się raczej jako reprezentacja rozumiana tu zgodnie z jej rozpoznaniem w kulturoznawstwie krytycznym, jak czasem określane są postcolonial studies ${ }^{14}$. Na dodatek wykazuje również wszelkie cechy „pojęcia wędrującego" (w rozumieniu Mieke Bal ${ }^{15}$ ), a jego podróżowanie realizuje się jednak nie tylko pomiędzy dyscyplinami (antropologia kultury, etnografia, etnologia, folklorystyka, socjologia, literaturoznawstwo), ale także pomiędzy różnymi obszarami pamięci kulturowej i społecznej w ich instytucjonalnych, politycznych i prawnych inkarnacjach. Nasycają one „kulturę ludową” własnymi kontekstami i znaczeniami, sprawiając, że jej wartość/zawartość desygnalna wraz z upływem czasu ulega coraz wyraźniejszemu rozmyciu. Rzec by można - po uwłaszczeniu chłopów kultura ludowa w Polsce natychmiast niemal podległa zawłaszczeniu/przejęciu, a proces ten trwa do dzisiaj ${ }^{16}$. Ten układ nieustających zależności „ludowej” od pańskiej, nieludowej, narodowej, polskiej rzetelnie prezentują tysiące prac jej fascynatów, orędowników, krytyków, badaczy, a w końcu i sami jej przedstawiciele, których wejście w pole produkcji kulturowej (na przykład tak zwany nurt wiejski w prozie), według Sulimy, najdobitniej „wyznacza kres historycznej (tradycyjnej) kultury chłopskiej”" ${ }^{17}$. Ten gest przystąpienia jego twórców (Julian Kawalec, Tadeusz Nowak, Stanisław Piętak, Wiesław Myśliwski, Marian Pilot, a dziś - Radek Rak z jego nagrodzoną Nike powieścią Baśń o wężowym sercu albo wtóre stowo o Jakóbie Szeli, by wskazać wyłącznie na literaturę) można uznawać, oczywiście, za proces i akt restytucji kultury ludowej, z przywołaniem całego pola semantycznego tejże restytucjiprzywrócenie czemuś dawnego stanu, przywrócenie gatunku zagrożonego wyginięciem, zwrot skonfiskowanego mienia, dążenie do przeproszenia osoby za wyrządzoną krzywdę, aby obniżyć poczucie winy, odtworzenie zabytku połączone z wbudowaniem oryginalnych, zachowanych elementów we właściwe im

${ }_{14}$ Zob. na przykład K. Jaskułowski, Kultura popularna jako pole bitwy. Wokót kulturoznawstwa krytycznego Stuarta Halla [w:] Ścięgna konsumpcyjne. Próby z kulturoznawstwa krytycznego, red. W.J. Burszta, M. Czubaj, Wrocław 2013, s. 51-77.

${ }_{15} \mathrm{M}$. Bal, Wędrujące pojęcia w naukach humanistycznych. Krótki przewodnik, tłum. M. Bucholc, Warszawa 2012.

${ }^{16}$ Kwestię zawłaszczenia kultury chłopskiej/ludowej, rozumianego tu jako poddawanie mechanizmom przemocy symbolicznej każdego nieomal z jej wymiarów (sfery duchowej, społecznej i materialnej) przez „zawsze lepiej wiedzące” grupy dominujące - inteligencję, władze polityczne, pisarzy, artystów, a w końcu i samych etnografów, omawiali już liczni, by wskazać choćby tylko na Józefa Bursztę, Kultura ludowa - kultura narodowa, Warszawa 1974; Franciszka Ziejkę, W kręgu mitów polskich, Kraków 1977, przywoływanego tu Rocha Sulimę, Jacka Kolbuszewskiego, Tatry w literaturze polskiej 1805-1939, Kraków 1982 czy Marię Janion, Do Europy tak, ale razem z naszymi umartymi, Warszawa 2000. Jedną z takich zawłaszczających (a powszechnych) praktyk jest folkloryzm, szeroko omówiony na łamach „Literatury Ludowej”. Lubelska rozmowa o folkloryzmie, „Literatura Ludowa” 1987, nr 4-6, s. 73-103. Na ten temat zob. też przypis nr 31 .

17 R. Sulima, Mity polskie..., dz. cyt., s. 101. 
miejsca ${ }^{18}-\mathrm{z}$ którego analizy trudno wszakże nie wyciągać wniosków o stojącej za tymi aktami degradacji, zagarnięciu, zagrożeniu wyginięcia gatunku oraz poczuciu winy, wynikającym z rozpoznania czynienia krzywdy. W tym miejscu należałoby ją rozmieć jako krzywdę zadawaną przez pole władzy, przemoc symboliczną wywieraną przez kulturę dominującą na podporządkowaną, która w odwecie, próbując rekonstruować i budować własny kapitał kulturowy, ale przyjmując jednak zasady „gry w ludowe”, posłużyła „odtworzeniu struktury dystrybucji kapitału kulturowego między grupami”"19, przyczyniając się jednocześnie do reprodukcji struktury społecznej, tak jak od stuleci służyła szlachcie, ziemianom, a potem i inteligencji. W realiach Polski Ludowej, kiedy to nastąpił boom nurtu chłopskiego w literaturze, a powołana na wniosek Ministerstwa Kultury i Sztuki oraz Biura Nadzoru Estetyki Produkcji (1949 rok) Centrala Przemysłu Ludowego i Artystycznego zajęła się oceną (i wyceną) poprawności „ludowego”, chłopskie nadal pozostawało chłopskie, czyli „inne”. Ideologiczne sito selekcji i autocenzura samych twórców przyczyniły się jednocześnie do zepchnięcia w „archiwalny niebyt” zapomnienia/wyparcia całych obszarów historycznej kultury chłopskiej, z jej specyficzną religijnością, stanowiącą światopoglądowy synoikizm katolicyzmu i myśli nieoswojonej (w rozumieniu Claude’a Levi-Straussa), czy na przykład sub-alter(natywnej) obyczajowości seksualnej, nie przystającej do obrazu „ludu pracującego miast i wsi”. Archiwa te, stanowiąc referencyjną pamięć społeczną ludu, tak zwaną bierną pamięć kulturową według Aleidy Assmann ${ }^{20}$, dobrze potwierdzają tezy współczesnych badaczy pamięci, że „[s] tosunek do przeszłości jest zawsze zależny od napięcia między memorią a amnezją" ${ }^{21}$, bo to właśnie sięgając do nich, potrafimy ustalić, co z racji działania przemocy symbolicznej musiało zastać zapomniane. W moim przekonaniu autentyczna kultura ludowa (w rozumieniu Edwarda Sapira) ${ }^{22}$ obecnie mieszka zatem w archiwach etnologów, badaczy

${ }^{18}$ Hasło „restytucja”, Wikipedia, https://pl.wikipedia.org/wiki/Restytucja, dostęp: 15.09.2020.

19 Zob. P. Bourdieu, J.-C. Passeron, Reprodukcja. Elementy teorii systemu nauczania, tłum. E. Neyman, Warszawa 2006, s. 84.

20 A. Assmann, Między historią a pamięcią. Antologia, tłum. różni, Warszawa 2013, s. 83.

${ }^{21}$ M. Sabrow, Die Lust an der Vergangenheit. Kommentar zu Aleida Assmann, „Zeithistorische Forschungen/Studies in Contemporary History” 2007, nr 4, s. 388. Cyt. za: M. Saryusz-Wolska, Postowie. Teorie pamięci Aleidy Assmann [w:] A. Assmann, dz. cyt., s. 313.

22 „Kultura autentyczna” - w znaczeniu, jakie nadaje temu pojęciu Sapir - nie jest typem kultury przypisanym jakiejś konkretnej fazie rozwojowej w dziejach kultur ludzkich. Może nią być kultura społeczeństwa zarówno bardziej „złożonego”, jak i „prostego”, „cywilizowanego” i „pierwotnego”, kultura „niska” lub „wysoka”, „plebejska” czy „elitarna”, „kształcona” czy „niekształcona”. Można ją - teoretycznie - pogodzić z każdym typem kultury narodowej, państwowej czy etnicznej. Cechy najszczególniejsze „kultury autentycznej” to: „harmonijność, równowaga, samozaspokojenie. Jest ona wyrazem bogato zróżnicowanej, a zarazem w jakiś sposób spójnej i jednolitej postawy wobec życia, postawy, która nadaje sens każdemu składnikowi cywilizacji, przyporządkowując go pozostałym jej elementom. Modelowo rzecz biorąc, nic w tej kulturze 
terenowych, folklorystów, a jej ostatniej syntezy dokonał w roku 1986 Ludwik Stomma w pracy Antropologia kultury wsi polskiej XIX wieku². Jako „twardy supeł” i reprezentacja „ludowości” istnieje ona jednak nadal w pamięci kulturowej Polaków i takiemu jej właśnie istnieniu należy przyjrzeć się bliżej, tym bardziej że po latach latencji, które nastąpiły po przewrocie w 1990 roku i odejściu od prezerwujących (i przemocowych) zabiegów władzy, teoretycznie niezabiegającej o reprodukcję struktur społecznych, kultura ludowa okazała się ponownie przedmiotem aktywności władzy/wiedzy. Najlepszym tego dowodem jest wdrażany od lat program Ministerstwa Kultury i Dziedzictwa Narodowego „Kultura ludowa i tradycyjna”, którego celem ,jest wspieranie zjawisk związanych ze spuścizną kultur tradycyjnych, transformacjami (przekształceniami i przemianami) poszczególnych elementów oraz współczesnymi kontekstami ich występowania" ${ }^{24}$. W jego ramach powstała i została opublikowana w 2014 roku jedna z ciekawszych współczesnych diagnoz kondycji kultury ludowej, bardzo dobrze pomyślana książka Kultura ludowa. Teorie - praktyki polityki, pod redakcją Barbary Fatygi i Ryszarda Michalskiego ${ }^{25}$, świetnie obrazująca miejsce „przeklętego problemu” ludowości jako imago „innego” bądź „naszego" we współczesnej kulturze polskiej. Zgromadzone w niej głosy antropologów, socjologów, etnologów, politologów, ale również jej animatorów, praktyków, twórców kapitalnie zdają sprawę z nieodmiennie istniejącego problemu ludowej przeszłości podrzędnej, którego zakres wpisałam w tytułową opozycję restytucja-zawłaszczenie, choć nie traktuję jej jako kategorycznie ustalającej bieguny szerokiego spektrum postaw wobec tego problemu przyjmowanych, ponieważ stojące za nimi działania niejednokrotnie wzajemnie się na siebie nakładają, wspierają i dopełniają. Najlepiej zdają się o tym świadczyć dzisiaj różnego rodzaju regulacje prawnomiędzynarodowe, takie jak Międzynarodowy pakt praw gospodarczych, społecznych i kulturalnych z 1966 roku, Konwencja UNESCO z 2003 roku $^{26}$, Konwencja ramowa Rady Europy o wartości

nie jest pozbawione duchowego znaczenia; żaden istotny dla jej znaczenia składnik nie niesie z sobą poczucia frustracji, bezcelowości, przymusu. Nie jest to unikająca harmonijnej syntezy duchowa chimera, pozszywana z niepasujących do siebie kawałków, sklecona ze szczelnie odseparowanych od siebie dziedzin świadomości”. E. Sapir, Kultura, język, osobowość, tłum. B. Stanosz, R. Zimand, A. Wierzbicka, Warszawa 1978, s. 181-182.

${ }^{23}$ L. Stomma, Antropologia kultury wsi polskiej XIX wieku, dz. cyt.

${ }^{24}$ Cyt. za: https://www.gov.pl/web/kultura/kultura-ludowa-i-tradycyjna2, dostęp: 15.09.2020.

${ }^{25}$ Kultura ludowa. Teorie - praktyki - polityki, dz. cyt.

${ }^{26}$ Zgodnie z rozpoznaniem Hanny Schreiber „Konwencja ta funkcjonuje na forum międzynarodowym już od 10 lat, a jej błyskawiczny sukces, mierzony szybko wzrastającą liczbą ratyfikacji (w grudniu 2012 r. było to już 148 państw na 193 państwa członkowskie Organizacji Narodów Zjednoczonych) powoduje, że stała się najważniejszym aktem prawa międzynarodowego w obszarze szeroko traktowanej kultury od 40 lat, czyli od czasu przyjęcia na forum UNESCO Konwencji w sprawie ochrony światowego dziedzictwa kulturalnego i naturalnego w 1972 r.". H. Schreiber, Konwencja UNESCO z 2003 roku: między prawnicza pewnościa 
dziedzictwa kulturowego dla społeczeństwa z 2005 roku oraz wiele innych, dla których ideową inspiracją była bez wątpienia Deklaracja w sprawie przyznania niepodległości krajom i narodom kolonialnym - Rezolucja Zgromadzenia Ogólnego ONZ z 14 grudnia 1960 roku. Wszystkie one, choć każda na swój sposób, rozbudziły dyskusję nad różnymi wymiarami przemocy i dominacji, w tym i przemocy symbolicznej oraz zawłaszczania dziedzictwa kultur mniejszych bądź ich marginalizowania. W takim demokratycznym z ducha nastawieniu podjęto się w nich wskazania instytucji za trwanie i rozwój tych kultur prawnie odpowiedzialnych, ale również wypracowania definicji przedmiotu prawnej ochrony. Za sprawą takich prawnomiędzynarodowych działań upowszechniło się w miarę neutralne pojęcie (materialnego i niematerialnego) dziedzictwa kulturowego. Rzeczowo i szczegółowo relacjonuje te kwestie we wskazanej wyżej pracy Hanna Schreiber, trafnie odnosząc je do polskich realiów:

W świetle obecnego brzmienia Rozporządzenia Ministra Kultury z 1 września 2005 r. w sprawie zakresu zadań objętych mecenatem państwa, szczegółowego trybu składania wniosków o udzielenie dotacji oraz trybu przekazywania i rozliczania udzielonych dotacji (Dz.U. nr 177, poz. 1474 ze zm.), do zadań objętych mecenatem państwa należy m.in. podtrzymywanie i rozpowszechnianie tradycji narodowej i państwowej, choć ogłoszone na tej podstawie programy, w ramach których można ubiegać się o dotację, wprowadzają jedynie priorytet „kultura ludowa” ${ }^{27}$.

Jak się okazuje, z perspektywy ministerialnej i państwa jako mecenasa kultura ludowa nadal istnieje, aczkolwiek wymaga specjalnej troski (!), pieczy i ochrony, co z jednej strony gwarantuje jej finansowanie, z drugiej zaś, co oczywiste podporządkowanie ${ }^{28}$. Praktyki restytucyjne wyraźnie pozostają tu w związku z polem władzy, co, rzecz jasna, nie jest wyłącznie polską domeną. Na naszym gruncie ujawnia się to zdecydowanie jasno w praktykach klasyfikacji ${ }^{29}$, jakiej kulturę tę poddano. Przypomnijmy bowiem, że pełna nazwa ministerialnego

a antropologicznymi watpliwościami (w 10-lecie istnienia konwencji: 2003-2013) [w:] Kultura ludowa. Teorie - praktyki-polityki, dz. cyt., s. 376.

27 Tamże, s. 380.

${ }^{28}$ Zgodnie z rekonstrukcją ministerialnej definicji, przeprowadzoną przez Barbarę Fatygę na podstawie analizy pola semantycznego celów i kryteriów programu MKiDN 2010 r. „kultura ludowa to kultura tradycyjna z elementami lokalnych $i$ spotecznych zmian” albo też „tradycyjna kultura regionalna, posiadająca autentyczne wartości, wymagająca popularyzacji”" (źródło: Cele); „unikalne elementy i cechy lokalne oraz konteksty społeczno-kulturowe, zachowująca charakterystyczne cechy lokalnego stylu” (źródło: Zadania), „kultura unikalna i typowa dla określonego regionu”, zgodna z regionalnymi cechami stylowymi, „dziedzictwo kulturowe regionu etnograficznego”, atrakcyjna, „styl życia oparty na aktywnym uczestnictwie w kulturze” (źródło: Kryteria). B. Fatyga, Zagadnienia i rekomendacje praktyczne [w:] Kultura ludowa. Teorie - praktyki-polityki, dz. cyt., s. 436.

29 W rozumieniu Aijaz Ahmad. Por. A. Ahmad, In Theory: Classes, Nations, Literatures, London 1992. 
jej opiekuna brzmi Ministerstwo Kultury i Dziedzictwa Narodowego. Podkreślając w tym miejscu fakt, iż w większości polskich sformułowań prawnych stale jest mowa o jednej kulturze ludowej ${ }^{30}$, jawiącej się tym samym jako mono$\mathrm{lit}^{31}$, wchodzi ona zatem w metonimiczny związek z dziedzictwem narodowym, w całych swych zasobach materialnych i niematerialnych ${ }^{32}$, stając się własnością wszystkich (?) Polaków. Rodzi to ponownie pytanie: „gdzie” zatem i ,jak” istnieje kultura ludowa dzisiaj?

Odpowiedzi na nie stara się udzielić we wspomnianej pracy (stanowiącej, nawiasem mówiąc, rezultat grantu Ministra Kultury i Dziedzictwa Narodowego) Barbara Fatyga (kulturoznawca, socjolog, antropolog kultury, kierownik Katedry Metod Badania Kultury i Ośrodka Badań Młodzieży w Instytucie Stosowanych Nauk Społecznych Uniwersytetu Warszawskiego). De facto zgadzając się z ministerialnymi rozstrzygnięciami co do istnienia kultury ludowej jako kultury żywej i twierdząc, iż „[t]eza o śmierci kultury ludowej (...) wydaje mi się - jak już wspominałam - absurdalna, a w świetle badań historyków kultury i innych specjalistów (...) trudna do sensownej obrony"33, podjęła się ona redefinicji kultury ludowej z uwzględnieniem wielości społeczno-kulturowych przemian, jakie zaszły od czasu pierwszego rozpoznania jej granic pojęciowych. W przekonaniu Fatygi nie ma bowiem „potrzeby rezygnowania

30 Obecnie, w 2019 roku, program MKiDN dotyczący zajmującego nas tu przedmiotu uzyskał brzmienie „Kultura ludowa i tradycyjna”. Zob. http://www.mkidn.gov.pl/pages/strona-glowna/finansowanie-i-mecenat/programy-ministra/programy-mkidn-2019/kultura-ludowa-i-tradycyjna.php, dostęp: 15.09.2020.

${ }^{31} \mathrm{Na}$ takie postrzeganie „kultury ludowej” zwracali uwagę już liczni badacze, jasno stwierdzając, iż wynika ono z mitologizacji stanowiącej też podstawę konstruowania jej modelu. We wspomnianym tomie trafnie diagnozuje to Ewa Klekot: „W polskiej etnologii pojawiły się głosy analizujące krytycznie "lud ludoznawców" (Zbigniew Libera, Stanisław Węglarz) oraz mechanizmy konstruowania przedmiotu badań ludoznawczych w XIX w. w obrębie dyskursu szlachecko-inteligenckiego. "Lud ludoznawców« jest Obcym tego dyskursu na podobnych zasadach, jak w dyskursie XIX-wiecznej antropologii Obcym jest kolonialny podporządkowany. Jednak pojęcie »ludu« i »ludowości« wymaga jeszcze wielu badań krytycznych - przede wszystkim, jeśli chodzi o jego absolutnie kluczową, instrumentalną rolę w konstrukcji polskiej ideologii narodowej w XIX w., kiedy priorytetem było zneutralizowanie fundamentalnego konfliktu społecznego między szlachtą i chłopami. Przemiana "gminu«, "chłopów«, "pospólstwa" w "polski lud« miała dokonać "cudu«, który wieszczył Zygmunt Krasiński w Psalmie mitości. "LUD« trzeba też zatem poddać refleksji jako UTOPIĘ szlachecko-inteligenckiej ideologii narodowej i krytycznie prześledzić wpływ ideologicznych determinant tego terminu w dyskursie ludoznawstwa i innych dyscyplin”. E. Klekot, Gtos w dyskusji. O kulturze ludowej: nigdy nie byto? jest czy jej nie ma? [w:] Kultura ludowa. Teorie - praktyki - polityki, dz. cyt., s. 66.

32 Zgodnie z art. 2 ust. 2 Konwencji UNESCO do niematerialnego dziedzictwa kulturowego należą się: „a) tradycje i przekazy ustne, w tym język jako nośnik niematerialnego dziedzictwa kulturowego; b) sztuki widowiskowe; c) zwyczaje, rytuały i obrzędy świąteczne; d) wiedza i praktyki dotyczące przyrody i wszechświata; e) umiejętności związane z rzemiosłem tradycyjnym". Cyt. za: H. Schreiber, dz. cyt, s. 376.

33 B. Fatyga, Nietad pojęciowy a program wspierania kultury [w:] Kultura ludowa. Teoriepraktyki-polityki, dz. cyt., s. 410 . 
z pojęcia kultury ludowej i zastępowania jej innym, nowocześniejszym pojęciem, ponieważ, w zależności od sposobu rozumienia kultury w ogóle, można też ów nowoczesny sens nadać temu pojęciu" ${ }^{34}$. Pomijając w tym miejscu fakt, iż w refleksji naukowej nad ontologią tej kultury raczej nie spotyka się wniosków o konieczności zrezygnowania z pojęcia „kultura ludowa”, ma ono bowiem istotną wartość operacyjną mimo braku realnego desygnatu zwanego „ludem”, Fatyga proponuje własne jej rozumienie:

kultura ludowa to specyficzna subkultura kultury współczesnej (żywej kultury). Składają się na nią konfiguracje praktyk kulturalnych oraz ich materialnych i niematerialnych wytworów. Kultura ludowa istnieje w perspektywie glokalizacyjnej, która zbiega się w każdym konkretnym wypadku w punkcie oznaczonym jako SWOJSKOŚĆ. Jej nosicielami i użytkownikami są współcześnie te jednostki i grupy społeczne, które, jak twierdzi Michel Maffesoli, przekraczają granice klas, wieku i przestrzeni, a którym zarazem dla funkcjonowania niezbędna jest KULTURA OSWOJONA I PRZYSTOSOWANA do doraźnego zaspokajania ich własnych codziennych i odświętnych potrzeb ${ }^{35}$.

Przyjąwszy, skądinąd zgodnie z klasyką socjologiczno-kulturowego myślenia o kulturowej partycypacji różnych grup społecznych (vide Andrzej Tyszka, choć niekoniecznie w zgodzie z filozofią społeczną Brunona Latoura, nie bez powodów powołującego się na Gabriela Tarde’a i jego wizje społecznego somnambulizmu ${ }^{36}$, że kultura ludowa jest subkulturą kultury polskiej i jako taka „zachowuje związki i relacje z całością kultury, a więc, iż zarówno podlega wpływom, jak i wywiera wpływ na inne subkultury oraz na całość kultury", wyliczyła także cechy praktyk i wytworów, stanowiące o jej istocie. Według niej są to:

1) BRICOLAGE, czyli tworzenie $z$ tego co pod rękq w celu zaspokojenia zarówno potrzeb poznawczych, jak i praktycznych, i estetycznych; warto zauważyć, że zasoby kulturowe, które wykorzystuje kultura ludowa, jak i wiedza oraz kompetencje techniczne, zmieniają się wraz ze zmieniającą się kulturą jako całością; nie ma się co obrażać, iż zmieniają się np. narzędzia;

2) WĘDRÓWKA i OSADZANIE SIĘ WZORÓW i WZORCÓW kulturowych w postaci klisz, motywów, toposów itd. W PRZESTRZENI GEOGRAFICZNEJ, ale także W PRZESTRZENI SPOŁECZNEJ (np. w i między warstwami czy klasami) oraz W CZASIE (np. rewitalizacja motywów);

34 Tamże, s. 413.

35 Tamże, s. 415.

36 B. Latour, Splatając na nowo to, co spoteczne. Wprowadzenie do teorii aktora-sieci, tłum. K. Abriszewski, A. Derra, Kraków 2010, s. 289-318. 
3) ORIENTACJA NA TERAŹNIEJSZOŚĆ (stąd podkreślane przez badaczy specyficzne znaczenie przeszłości, np. instrumentalne jej traktowanie do uzasadniania i legitymizowania sytuacji mających miejsce tu $i$ teraz, koncepcje czasu cyklicznego, wiecznej teraźniejszości itp., ale także permanentny, chociaż bardzo często zapoznawany, dziejący się w różnych tempach, proces przekształcania się kultury ludowej ${ }^{37}$.

Przytaczam tu szeroko ustalenia badaczki, ponieważ oddają one wyraziście proces jej dochodzenia do finalnego rozstrzygnięcia, a mianowicie utożsamienia współczesnej kultury ludowej z kulturą popularną bądź - jak kto woli - odwrotnie, popularnej z ludową, co prowokuje głębszy namysł kulturoznawczy. Proponując własną, przybliżoną definicję kultury ludowej Fatyga (za Maffesolim) uznaje, że jej użytkownikami są współcześnie te jednostki i grupy społeczne, którym dla funkcjonowania niezbędna jest KULTURA OSWOJONA I PRZYSTOSOWANA do doraźnego zaspokajania ich własnych codziennych i odświętnych potrzeb (zob. wyżej), co rodzi pytanie natury czysto antropologicznej: czy możemy wskazać takie grupy i jednostki, którym kultura oswojona i przystosowana do zaspokojenia ich codziennych i odświętnych potrzeb jest zbędna? Jeśli przyjmiemy uznawaną przez większość antropologów definicję Ralpha Lintona, że kultura to „konfiguracja wyuczonych zachowań i ich rezultatów, których elementy składowe są podzielane i przekazywane przez członków danego społeczeństwa" ${ }^{38}$, wraz z całą towarzyszącą jej Lintonowską wykładnią, przykładów takich grup i jednostek raczej nie znajdziemy, ponieważ nawet najbardziej dysfunkcyjne i zdezintegrowane kultury, takie jak opisywana przez Colina Turnbulla kultura Ików ${ }^{39}$, przejawiały cechy „oswojenia i przystosowania” do ich doraźnych, codziennych i odświętnych potrzeb. Inaczej mówiąc, antropologicznie trudna do wyobrażenia jest sytuacja czyjegoś nieuczestniczenia w kulturze. Niemniej z perspektywy socjologii (kultury), która z całości kultury wyodrębniła dla siebie względnie autonomiczny sektor, nadając mu miano „kultury w węższym rozumieniu” lub „kultury symbolicznej" - przedmiot komunikowania symbolicznego ${ }^{40}$, stan nieuczestniczenia w nieoswojonym i nieprzystosowanym jest możliwy, acz w dobie mass mediów mocno utrudniony. Musiałby zakładać izolację, zamknięcie lub przynajmniej światopoglądowe filtrowanie napływających z zewnątrz treści, co notabene zostało wpisane przez antropologów kultury wsi w jej specyfikę ${ }^{41}$. Czy uchylenie tego warunku nadal pozwala nam mówić o kulturze ludowej jako „żywej” kulturze, czy może jednak właśnie, jak pisałam wyżej, jako wcielonej

37 B. Fatyga, Nietad pojęciowy a program wspierania kultury, dz. cyt., s. 417.

${ }_{38}$ R. Linton, Kulturowe podstawy osobowości, tłum. A. Jasińska-Kania, Warszawa 1975.

39 C.M. Turnbull, Ikowie, ludzie gór, tłum. B. Kuczborska, Warszawa 1980.

40 Por. A. Kłoskowska, Socjologia kultury, Warszawa 1981.

${ }^{41}$ Por. między innymi L. Stomma, Antropologia kultury wsi polskiej XIX wieku, dz. cyt. 
i niewcielonej pamięci archiwów, otwartych obecnie „złotym kluczem” dziedzictwa narodowego, dzięki czemu każdy może z nich czerpać dowolnie i pełnymi garściami, jeśli tylko chce?

Jak pokazują Barbara Fatyga oraz autorzy wypowiedzi zgromadzonych w zredagowanej przez nią pracy (szczególnie zaś Kuba Szpilka, Maciej Żurek, Stanisława Trebunia-Staszel), a przede wszystkim, jak wykazują wyniki kolejnych edycji Programu Ministra Kultury i Dziedzictwa Narodowego - chętnych jest wielu ${ }^{42}$. Patrząc z perspektywy obiegu i recepcji obiektów kulturowych, z których każdy „musi mieć więc kogoś, kto go słucha, czyta, rozumie, myśli o nim, odgrywa go, uczestniczy w nim i go pamięta" ${ }^{43}$, a więc perspektywy socjologii kultury, kultura ludowa rzeczywiście jest dziś popularna, także w znaczeniu, jakie nadaje jej John Fiske ${ }^{44}$, staje się bowiem obiektem twórczej aktywności jej konsumentów, przejawiającej się między innymi w wykorzystaniu, nadużyciu, przywłaszczeniu, niszczeniu, ale również nadawaniu jej obiektom nowych, własnych znaczen ${ }^{45}$. W tej sytuacji być może zatem rzeczywiście, jak twierdzi Fatyga, „nie ma się co obrażać, iż zmieniają się np. narzędzia”. Jeśli jednak zmieniają się narzędzia i treść/sens obrabianej nimi materii oraz kontekst użycia tak przepracowanego obiektu, czy wciąż możemy mówić o tym samym obiekcie? Czy Szekspirowski dramat Romeo i Julia przeniesiony w filmowej adaptacji do współczesności ${ }^{46}$, gdzie zamiast zamków pojawiają się drapacze chmur, szpady zostały zamienione na pistolety, a milionowa publiczność zgromadzona przed ekranami kin wszystkich zakątków świata płacze nad nieszczęśliwą miłością dwojga młodych, to nadal teatr epoki elżbietańskiej? I per analogiam, czy na przykład oczepiny (fragment obrzędu przejścia realizowanego podczas tradycyjnego wesela chłopskiego) odgrywane na scenie festiwalowej, poza właściwym im kontekstem rites de passage, głęboko przeżywanych

${ }^{42}$ Według statystyk przedstawionych przez Fatygę i zespół pośród beneficjentów programu MKiDN w roku 2011 32\% stanowili organizatorzy konkursów, przeglądów i festiwali, 28\% organizatorzy warsztatów, kursów i szkoleń, $23 \%$ podmioty działające na rzecz ochrony i dokumentacji, 16\% skierowano do przedsięwzięć edukacyjnych, a tylko $1 \%$ przeznaczono na rzecz ochrony unikatowych elementów kultury ludowej. B. Fatyga, Wnioski z analizy „Programu Ministra Kultury..." [w:] Kultura ludowa. Teorie - praktyki - polityki, dz. cyt., s. 439.

${ }^{43}$ W. Griswold, Socjologia kultury. Kultury i spoteczeństwa w zmieniającym się świecie, tłum. P. Tomanek, Warszawa 2013, s. 46.

${ }^{44}$ J. Fiske, Zrozumieć kulturę popularna, tłum. K. Sawicka, Kraków 2010.

${ }^{45} \mathrm{Na}$ potrzeby projektu Obserwatorium Żywej Kultury - Sieć Badawcza (por. www.ozkultura.pl), któremu przyświeca zamysł zmapowania współczesnej kultury polskiej, stworzono Indeks działań i wydarzeń, w którym uwzględniono kulturę ludową jako żywą, a obejmującą: Andrzejki, biesiady, chrzciny, dni (na przykład wagarowicza/inne), dożynki, festyny, festy, fiesty, grzybobrania, jarmarki, jubileusze, Katarzynki, kiermasze, kolędy, komunie, majówki, Noce świętojańskie, ostatki, pograjki, pokazy, posiady, powitania wiosny/inne, pożegnania lata/inne, rocznice, Sobótki, święta patronów/inne, targi, topienie Marzanny/inne, warsztaty, wesela ludowelregionalnelinne, wianki, wybory palmy wielkanocnej, wyścigi kumotereklinne, zapusty, zabawy ludowe. B. Fatyga, Nietad pojęciowy a program wspierania kultury, dz. cyt., s. 409.

${ }^{46}$ Film Romeo i Julia, reż. B. Luhrmann, 1996. 
przez wszystkich uczestników/wykonawców w konkretnej sytuacji wesela, to nadal „żywy” obrzęd, „żywa” kultura ludowa? Restytucja to jej czy zawłaszczenie?

Pozostawiając to pytanie otwartym, zakończę te rozważania ich artystycznym dopełnieniem w wersji zaproponowanej ongiś przez Kazimierza Grześkowiaka:

Ten pan zgłupiał chyba z wszyćkim

Łaps! i wyją mnie z kapliczki

A na koniec tej sromoty

Gdzieś do miasta wywiózł potem.

Rzekła tego pana żona:

Świątka damy do salona.

A tam u nas jesień cicha

Kwiat umiera, pieśń usycha.

Cnót rarytasie, kwiatuszku woniący

W dni postowania od piersi stroniący

Precz oddaliłeś od się sprośne chęci

I to co nęci.

Od powietrza morowego

No i od wszelkiego złego

Salon nieźle jest chroniony

W kącie wiszą dwie ikony

Budda się w czystości nurza

Pani nowy ma odkurzacz.

A tam u nas jesień cicha

Kwiat umiera, pieśń usycha ${ }^{47}$.

\section{Bibliografia}

Ahmad A., In Theory: Classes, Nations, Literatures, London 1992.

Assmann A., Między historia a pamięcią. Antologia, tłum. różni, Warszawa 2013.

Bal M., Wędrujace pojęcia w naukach humanistycznych. Krótki przewodnik, tłum. M. Bucholc, Warszawa 2012.

Bourdieu P., Passeron J.-C., Reprodukcja. Elementy teorii systemu nauczania, thum. E. Neyman, Warszawa 2006.

Burszta W., Etnografia ludowości [w:] Kultura ludowa. Teorie - praktyki - polityki, red. B. Fatyga, R. Michalski, Warszawa 2014.

${ }^{47}$ K. Grześkowiak, Salonowy świątek, http://grzeskowiak.art.pl/utwory/salonowy_swiatek.html, dostęp: 15.09.2020. 
Burszta J., Kultura ludowa - kultura narodowa, Warszawa 1974.

Burszta J., Kultura ludowa [w:] Stownik etnologiczny: terminy ogólne, red. Z. Staszczak, Warszawa-Poznań 1987.

Chakrabarty D., Historie mniejszości, przesztości podrzędne, tłum. E. Domańska [w:] Teoria wiedzy o przesztości na tle wspótczesnej humanistyki, red. E. Domańska, Poznań 2010.

Czarnowski S., Podtoże ruchu chtopskiego [w:] tegoż, Dzieta, t. 2, Warszawa 1956. Dobrowolski K., Studia nad teoria kultury ludowej, „Etnografia Polska” 1961, t. 4. Fatyga B., Nietad pojęciowy a program wspierania kultury [w:] Kultura ludowa. Teorie - praktyki-polityki, red. B. Fatyga, R. Michalski, Warszawa 2014.

Fatyga B., Wnioski z analizy „Programu Ministra Kultury...” [w:] Kultura ludowa. Teorie - praktyki - polityki, red. B. Fatyga, R. Michalski, Warszawa 2014

Fatyga B., Zagadnienia i rekomendacje praktyczne [w:] Kultura ludowa. Teorie praktyki-polityki, red. B. Fatyga, R. Michalski, Warszawa 2014.

Fiske J., Zrozumieć kulture popularna, tłum. K. Sawicka, Kraków 2010.

Giddens A., Nowoczesność i tożsamość. "Ja” i spoteczeństwo w epoce późnej nowoczesności, tłum. A. Szulżycka, Warszawa 2002.

Griswold W., Socjologia kultury. Kultury i spoteczeństwa w zmieniającym się świecie, tłum. P. Tomanek, Warszawa 2013.

Grześkowiak K., Salonowy świątek, http://grzeskowiak.art.pl/utwory/salonowy_ swiatek.html, dostęp: 15.09.2020.

Hasło „restytucja”, Wikipedia, https://pl.wikipedia.org/wiki/Restytucja, dostęp: 15.09.2020.

Janion M., Do Europy tak, ale razem z naszymi umartymi, Warszawa 2000.

Jaskułowski K., Kultura popularna jako pole bitwy. Wokót kulturoznawstwa krytycznego Stuarta Halla [w:] Ściegna konsumpcyjne. Próby z kulturoznawstwa krytycznego, red. W.J. Burszta, M. Czubaj, Wrocław 2013.

Kabzińska I., Jubileusz sześćdziesięciolecia „Etnografii Polskiej”. Kontynuacja poczatkowych zatożeń - nowe nurty $i$ tematy - pytania i refleksje, „Etnografia Polska” 2016, t. LX, z. 1-2.

Klekot E., Gtos w dyskusji. O kulturze ludowej: nigdy nie byto? jest czy jej nie ma? [w:] Kultura ludowa. Teorie - praktyki - polityki, red. B. Fatyga, R. Michalski, Warszawa 2014.

Kłoskowska A., Socjologia kultury, Warszawa 1981.

Kolbuszewski J., Tatry w literaturze polskiej 1805-1939, Kraków 1982.

Lakatos I., Pisma z filozofii nauk empirycznych, tłum. W. Sady, W. Krajewski, Warszawa 1995.

Latour B., Splatając na nowo to, co spoteczne. Wprowadzenie do teorii aktora-sieci, tłum. K. Abriszewski, A. Derra, Kraków 2010.

Linton R., Kulturowe podstawy osobowości, tłum. A. Jasińska-Kania, Warszawa 1975.

Lubelska rozmowa o folkloryzmie, „Literatura Ludowa” 1987, nr 4-6. 
Ministerstwo Kultury i Dziedzictwa Narodowego, Programy 2019, Kultura ludowa i tradycja, http://www.mkidn.gov.pl/pages/strona-glowna/finansowaniei-mecenat/programy-ministra/programy-mkidn-2019/kultura-ludowa-i-tradycyjna.php, dostęp: 15.09.2020.

Ministerstwo Kultury i Dziedzictwa Narodowego, Programy 2020, Kultura ludowa i tradycja, https://www.gov.pl/web/kultura/kultura-ludowa-i-tradycyjna2, dostęp: 15.09.2020.

Sabrow M., Die Lust an der Vergangenheit. Kommentar zu Aleida Assmann, „Zeithistorische Forschungen/Studies in Contemporary History” 2007, nr 4.

Sapir E., Kultura, język, osobowość, tłum. B. Stanosz, R. Zimand, A. Wierzbicka, Warszawa 1978.

Saryusz-Wolska M., Postowie. Teorie pamięci Aleidy Assmann [w:] A. Assmann, Między historia a pamięcia. Antologia, Warszawa 2013.

Schreiber H., Konwencja UNESCO z 2003 roku: między prawnicza pewnościa a antropologicznymi watpliwościami (w 10-lecie istnienia konwencji: 2003-2013) [w:] Kultura ludowa. Teorie - praktyki - polityki, red. B. Fatyga, R. Michalski, Warszawa 2014.

Spivak G.Ch., Czy podporządkowani inni moga przemówić?, tłum. E. Majewska, „Krytyka Polityczna” 2010, 24-25.

Staszic S., Przestrogi dla Polski, Warszawa 1790.

Stomma L., Antropologia kultury wsi polskiej XIX wieku, Warszawa 1986.

Stomma L., Determinanty polskiej kultury ludowej XIX wieku, „Konteksty. Polska Sztuka Ludowa” 1978, nr 3.

Sulima R., Mity polskie i mity ludowe [w:] tegoż, Gtosy tradycji, Warszawa 2001.

Ścięgna konsumpcyjne. Próby z kulturoznawstwa krytycznego, red. W.J. Burszta, M. Czubaj, Wrocław 2013.

Turnbull C.M., Ikowie, ludzie gór, tłum. B. Kuczborska, Warszawa 1980.

Ziejka F., W kręgu mitów polskich, Kraków 1977. 